\title{
COMPARISON OF THE RESULTS OF ANALYTICAL AND NUMERICAL MODELS OF PRE-REINFORCEMENT IN SHALLOW TUNNELS
}

\author{
D. PEILA ${ }^{1}$, C. MARCHINO ${ }^{2}$, C. TODARO ${ }^{3}$, A. LUCIANI $^{4}$
}

\begin{abstract}
The steel pipe umbrella is a widely used technology when tunnelling in weak soils in order to create pre-support ahead of the tunnel face. The design of steel pipes is frequently done through simplified analytical approaches which are easy to apply but require proper assessment of the loads acting on the pipe. To provide information on this key design aspect, the results of the comparison between a three-dimensional numerical model developed with the code FLAC 3D and an analytical model based on the approach of a beam on yielding supports is presented and discussed. The comparison refers to a shallow tunnel with an overburden of three times its diameter for two different types of weak rock masses. The obtained results provide suggestions about the load that has to be applied in the analytical model for the design phase.
\end{abstract}

Keywords: Tunnel construction, pre-reinforcement, steel pipes, numerical modelling, analytical models

\section{INTRODUCTION}

The steel pipe umbrella system is a ground reinforcement technique widely used in tunnelling excavation in poor soil frequently coupled with face reinforcement with fibre-glass pipes. Steel pipes are installed in the ground on the crown of the tunnel boundary ahead of the tunnel face in order to improve the self-supporting capacity of the rock mass, thus permitting a safe installation of supports (steel arches and shotcrete) and, in shallow tunnels, to guarantee the stability of the surface and to minimize settling (Pelizza and Peila, 1993; Hoek, 2001; Peila and Pelizza, 2003; Volkmann

\footnotetext{
${ }^{1}$ Prof., Politecnico di Torino, DIATI, C.so Duca degli Abruzzi 24, 10129 Torino, Italy, e-mail: daniele.peila@polito,it

${ }^{2}$ Eng., Consultant, Torino, e-mail: chiaramarchino644@gmail.com

${ }^{3}$ Eng, Politecnico di Torino, DIATI, C.so Duca degli Abruzzi 24, 10129 Torino, Italy, e-mail: carmine. todaro@polito.it

${ }^{4}$ Eng., Politecnico di Torino, DIATI, C.so Duca degli Abruzzi 24, 10129 Torino, Italy, e-mail: andrea.luciani@polito.it
} 
at. Al, 2006; Volkmann and Schubert, 2007; Aksov and Onargan, 2010; Merlini and Stocker, 2011; Sorlini et al., 2012).

Frequently, this technology is coupled with the installation of fiberglass pipes used to stabilize the tunnel face guaranteeing a safe embedding of the pipes in the soil. Since the seventies this technique has been widely used thanks to its wide field of applicability, ranging from good quality rock masses to soils, even in cases of shallow tunnels (Barisone et al., 1982; 1983; Carrieri et al., 1983, 2002; Shin et al. 2008; Schubert, 2011), but its design has some unavoidable complexity due to the three-dimensional geometry conditions in the tunnel face.

The design is often done through simplified analytical approaches, based on the definition of external loads acting on the pipe modelled as a beam on yielding supports (Peila and Pelizza, 2003; Marchino et al., 2010). The three-dimension numerical model is also frequently used but they are affected by the complexity of the calculation procedure and by the difficulties and uncertainties connected to the initialization and interpretation of a numerical model's results (Peila, 1994; Oreste and Peila, 1998; 2000), Furthermore, setting up a three-dimensional model is still a complex and time consuming procedure as of today.

The analytical approach that is usually adopted requires the schematization of each pipe as a beam subjected to a distributed pressure. Connection of the pipe with steel ribs installed in the excavated part of the tunnel are simulated as punctual supports.

Ahead of the tunnel face the beam is embedded in the soil or into the rock mass, therefore the pipe interlocking into the ground is modelled with springs that can be designed applying the Winkler scheme, as is usually done in foundation engineering (Bowels, 1988; Lancellotta and Calavera, 1999). The ground load, acting on the beam, is usually considered as a percentage of the total Terzaghi load (Bieniawski, 1989) when tunnelling at medium to great depth, or equal to the whole ground load when the tunnel coverage is less than the tunnel diameter. The greatest uncertainty of this well-consolidated methodology lies in the correct definition of the load that has to be applied to the beam, a value that is also greatly influenced by the position of the advancing tunnel face due to the formation of the arch effect at the face (Oreste et al., 1999; Barpi et al., 2011, Lunardi, 2008; Galli et al., 2004).

To improve the knowledge of this aspect, it is possible to carry out a comparison of the displacements and stresses in the pipe between the analytical approach described above and a threedimensional numerical model. This comparison allows us to better understand the steel pipe umbrella behaviour and to provide suggestions about the design load to be applied to the pipe. 


\section{DESCRIPTION OF THE NUMERICAL MODEL}

The three-dimension numerical model has been developed with the finite difference code FLAC 3D (Ver. 3.1) and is composed of about 275.500 quadrilateral constant-stress elements. The model simulates the excavation of two horseshoe shaped tunnels, each with an area of $170 \mathrm{~m}^{2}$ and a coverage of approximately three diameters (Fig. 1). The analysis is referred to real tunnel geometry under construction in the Apennine mountains (Italy). Although the geometry of the model is designed to analyse the excavation of two parallel tunnels, the present research refers to the excavation of only one tunnel (the right one) with the focus to study the stabilizing effects of presupports. Since the tunnel coverage is low, the initial state of stress acting on the model in an undisturbed condition is gravitational. The geometry of the tunnel and the boundary conditions of the model are summarized in Figs 1 and 2. The excavation is simulated considering two different sets of geotechnical parameters as reported in Table 1, correspondent to an arenaceous and an argillite flysch.

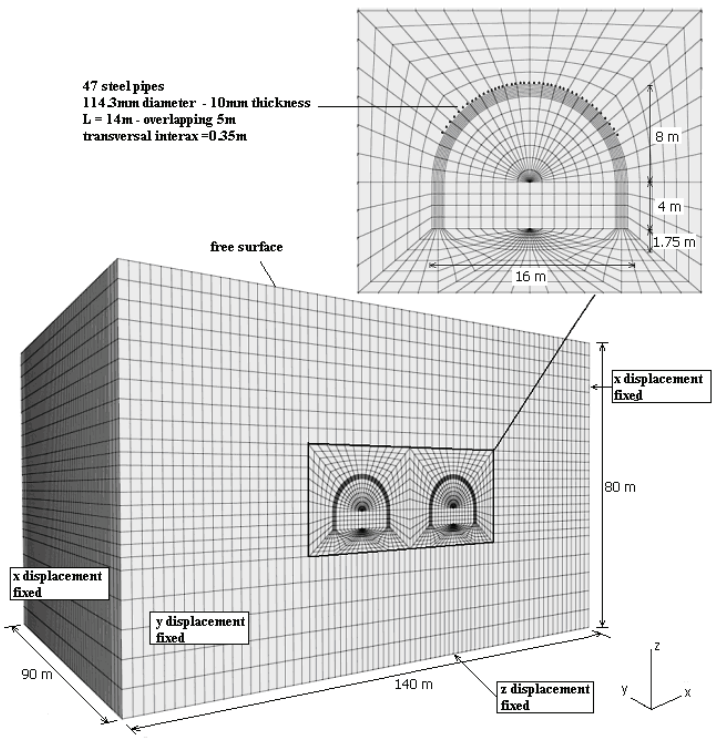

Fig. 1. Numerical model geometry, boundary conditions, dimensions, and positions of steel pipes. In the research, the excavation of only one tunnel is considered and therefore modelled. 
Both rock masses are modelled with an elasto-plastic constitutive law and a Mohr-Coulomb yield criterion. The excavation of the tunnel is simulated for an advancing length of $1 \mathrm{~m}$, a common value when using ground reinforcement ahead of the face. In the numerical model it is assumed that when the excavation of the advancing step ( $\mathrm{i}+1)$ is done, in the previous step, already excavated (i), the first phase supports are installed (Fig. 3). These supports are composed of steel ribs and a shotcrete layer and they are modelled with shell elements. The properties of these supports have been evaluated with the approach of equivalent material as proposed by Hoek et al. (2008); an equivalent elastic modulus equal to $32.000 \mathrm{MPa}$ and a shell thickness of $0.23 \mathrm{~m}$ were considered. Steel pipes have been modelled with beam elements that are mono-dimensional with axial and bending stiffness, while the fibre-glass elements for face reinforcement - installed on the face - have been modelled with cable elements that are mono-dimensional with axial stiffness and no strength to the bending moments (Tables 2 and 3).
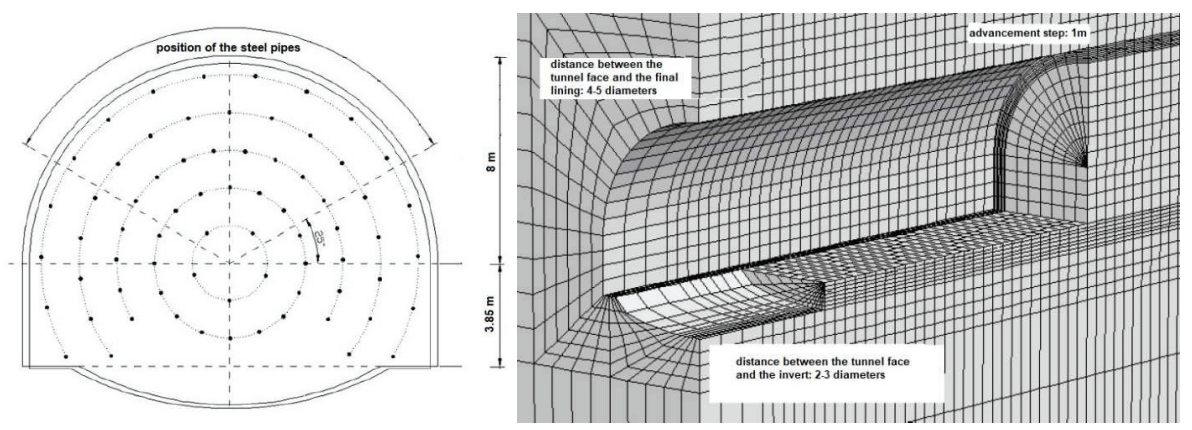

Fig. 2. Geometry of the tunnel at the tunnel face, position of the modelled face reinforcement, and detail of the position of the final lining with reference to the tunnel face.

Table 1. Geo-mechanical parameters of rock masses

\begin{tabular}{|l|r|r|}
\hline \multicolumn{1}{|c|}{ Parameter } & Arenaceous flysch & \multicolumn{1}{c|}{ Argillite flysch } \\
\hline Unit weight $\left[\mathrm{kN} / \mathrm{m}^{3}\right]$ & 25 & 25 \\
\hline Deformability modulus $[\mathrm{MPa}]$ & 2000 & 1200 \\
\hline Poisson ratio $[-]$ & 0.25 & 0.27 \\
\hline Friction angle $\left[{ }^{\circ}\right]$ & 40 & 37 \\
\hline Cohesion $[\mathrm{kPa}]$ & 80 & 60 \\
\hline Uniaxial compressive strength $[\mathrm{MPa}]$ & 4 & 1.2 \\
\hline GSI & $30-35$ & $25-30$ \\
\hline
\end{tabular}


Table 2. Properties of the cable elements used to model the fibre-glass reinforcements

\begin{tabular}{|l|r|}
\hline Unit weight $\left[\mathrm{kN} / \mathrm{m}^{3}\right]$ & 19 \\
\hline Elastic Modulus [MPa] & 15000 \\
\hline Cross section $\left[\mathrm{mm}^{2}\right]$ & 2290 \\
\hline Uniaxial compressive strength of the mortar [MPa] & 5 \\
\hline Shear strength of the mortar [GPa] & 9 \\
\hline Friction angle of the mortar $\left[{ }^{\circ}\right]$ & 0 \\
\hline
\end{tabular}

Table 3. Properties of the beam elements used to model the steel pipes

\begin{tabular}{|l|r|}
\hline Unit weight $\gamma\left[\mathrm{kN} / \mathrm{m}^{3}\right]$ & 78 \\
\hline Elastic modulus [MPa] & 206000 \\
\hline Poisson modulus of the steel $[-]$ & 0.3 \\
\hline Cross section $\left[\mathrm{mm}^{2}\right]$ & 3300 \\
\hline Inertia moment $\left[\mathrm{m}^{4}\right]$ & $4.5 \mathrm{E}-6$ \\
\hline
\end{tabular}

\section{ANALITICAL MODEL}

The analytical model presented is based on the key concept that each steel pipe acts as a single independent beam since the grouting around the pipe is considered to not be able to create a continuous arch (Peila and Pelizza, 2003; Hoek, 2001).

The used static scheme refers to a Winkler beam on multiple supports (Oreste and Peila, 1998) (Fig. 4). Each support is modelled with a spring whose behaviour is related to the rock-mass properties (ahead of the face) and to the supporting capacity of the steel rib foundation (behind the face). In the present research, the stiffness of the spring ahead of the face has been defined on the basis of the stiffness parameters defined by Bowels (1988) for different soils and usually applied in the field of surface foundations. In detail, a stiffness of $60 \mathrm{kN} / \mathrm{mm}$ was considered for the arenaceous flysch that corresponds to a $\mathrm{k}_{\mathrm{s}}$ value equal to $1500 \mathrm{MN} / \mathrm{m}^{3}$, while a stiffness of $40 \mathrm{kN} / \mathrm{mm}$ ( $\mathrm{k}_{\mathrm{s}}$ equal to $1000 \mathrm{MN} / \mathrm{m}^{3}$ ) was used for the argillite flysch. The steel ribs were modelled both as fixed and yielding supports to take into account the possibility of the settling of their foundations.

The applied loads were considered ranging from $1 / 2$ to $1 / 6$ of the Terzaghi load (about $90 \mathrm{kN} / \mathrm{m}$ ). 


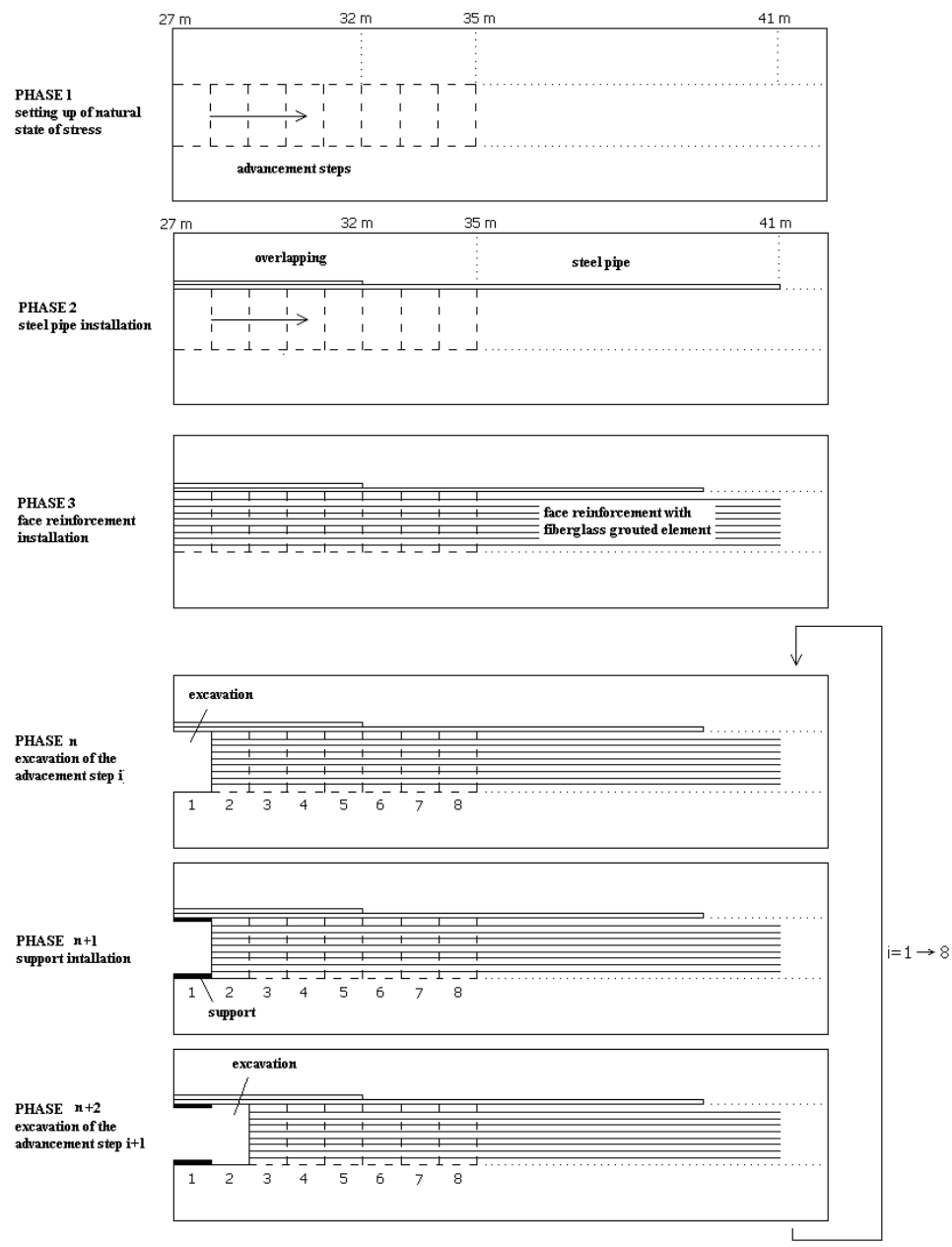

Fig. 3. Modelled construction sequence and advancing steps

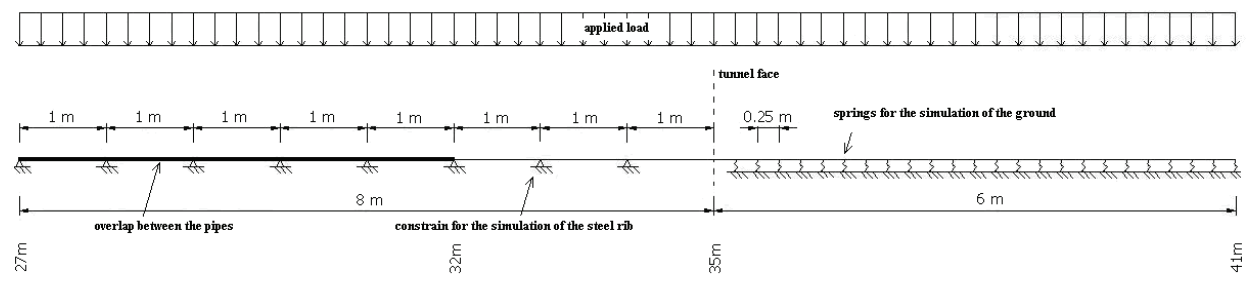

Fig. 4. Analytical scheme used for the multi-supported beam approach. 


\section{DiSCUSSION OF RESULTS}

The results of the calculation with the two different models have been expressed in terms of bending moments and vertical displacements of the beam in Figs. 5, 6, 7, and 8.

The stresses acting on the beam, according to the numerical model and to the analytical approach, are relatively close if a correct value of the applied load is considered; the differences depend on two aspects:

- the analytical model does not consider the overlapping between two adjacent umbrellas;

- the shell element used to model preliminary supports in the numerical model is more adequate to simulate the action of steel ribs and the shotcrete layer than the punctual support applied in the analytical model.

The analysis of displacements shows that the use of infinitely stiff steel rib connections (fixed supports) is conservative, while a better agreement with numerical results can be achieved when flexible supports are considered (Fig. 8, curves A, B, C).

A greater difference between the analytical and the numerical results has been observed in the area immediately behind the tunnel face.

This effect is probably due to the impossibility of taking into account the face extrusion with the analytical model. This problem can be managed in the analytical approach by fictitiously reducing the stiffness of the springs in the last $4 \mathrm{~m}$ behind the face, as can be observed in Figure 8 where the curve $\mathrm{D}$, obtained by reducing the stiffness of beams immediately behind the tunnel face to $1 / 6$ of their original value, gives a better fitting with numerical results.

In general terms, the calculations have shown that for a shallow tunnel (i.e. with a coverage less than 2.5-3 times the tunnel diameter) a load applied to the pipe equal or slightly lower than the Terzaghi load leads to conservative results. Near the tunnel face, a bending moment distribution compliant with the numerical model can be found by applying to the pipe a load ranging between $1 / 4$ and $1 / 3$ of the total Terzaghi load, both for the arenaceous and argillite flysch. With reference to pipe displacements, the proposed analytical model with fixed supports is not able to give a reasonable approximation of the effective steel pipe vertical displacements, because it does not allow a displacement of the steel rib foundation. This limit can be overcome by replacing fixed supports with yielding springs, whose stiffness can be set between $5 \mathrm{kN} / \mathrm{mm}$ and $10 \mathrm{kN} / \mathrm{mm}$, with an acting load on the pipe equal to $1 / 4$ of the Terzaghi load. Under these conditions the displacements of the pipe according to the analytical approach and the numerical model are wellmatched with each other. 


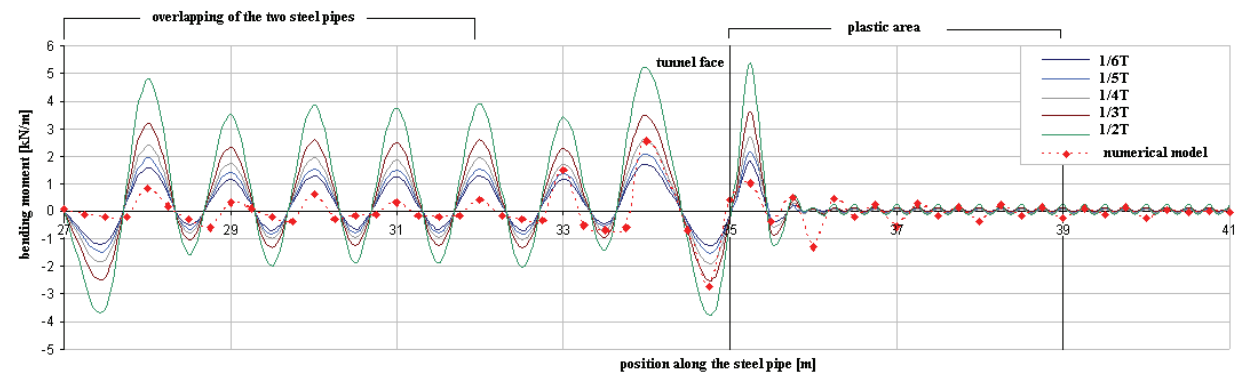

Fig. 5. Bending moments acting along the pipe, argillite flysch.

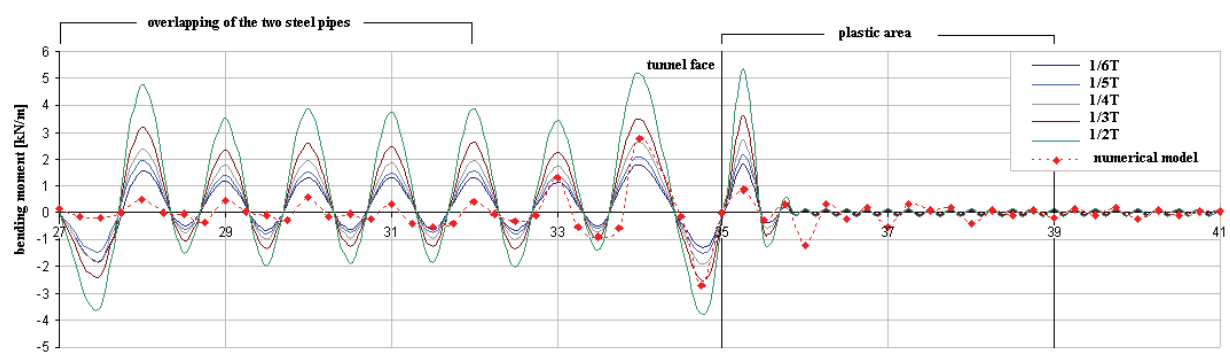

position along the steel pipe [m]

Fig. 6. Bending moments acting along the pipe, arenaceous flysch.

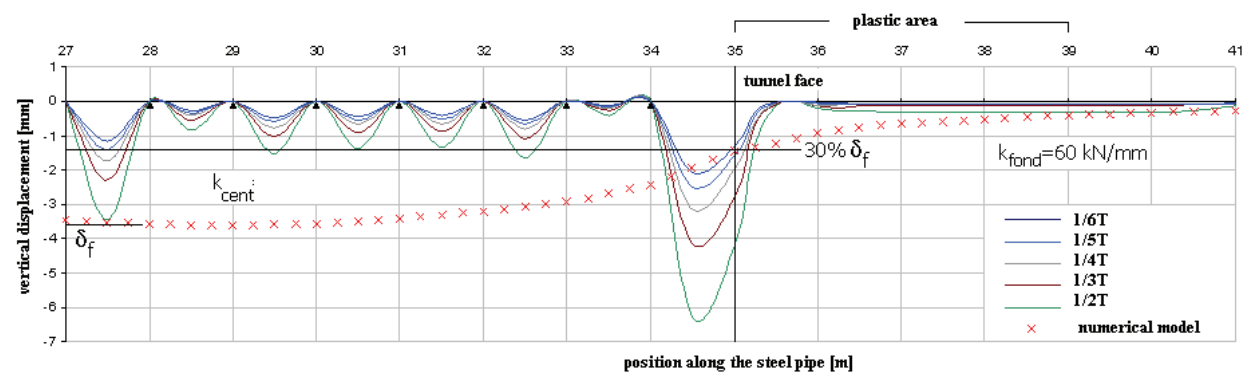

Fig. 7. Numerically computed vertical displacements compared with analytical results for the pipe in the middle of the crown in the sandstone rock mass. 


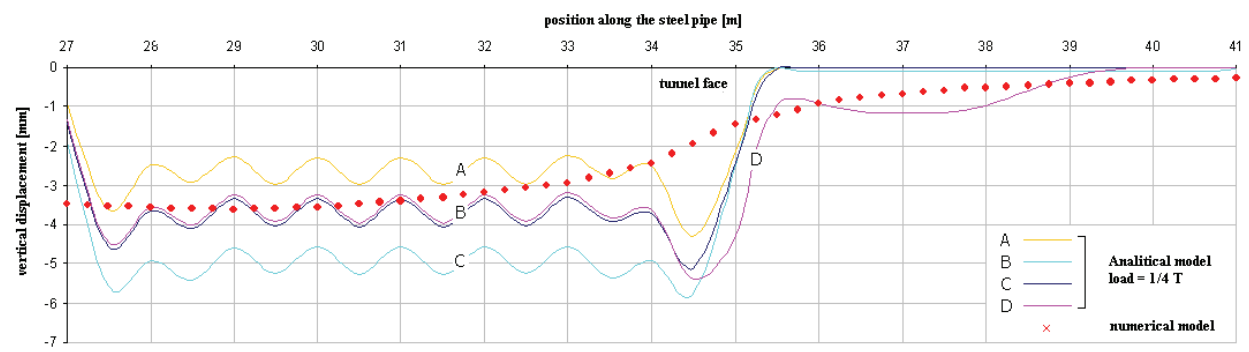

Fig. 8. Numerically computed vertical displacements compared with analytical results for the pipe in the middle of the crown in the sandstone rock mass reducing the stiffness of the spring for the simulation of the steel arches and their foundations ( $\mathrm{k}_{\text {fond }}$ and $\left.\mathrm{k}_{\mathrm{cent}}\right)$.

Key: Curve A: $\mathrm{k}_{\text {cent }}=10 \mathrm{kN} / \mathrm{mm}, \mathrm{k}_{\text {fond }}=60 \mathrm{kN} / \mathrm{mm}$ for the whole length of the steel pipe; Curve B: $\mathrm{k}_{\text {cent }}=8$

$\mathrm{kN} / \mathrm{mm}, \mathrm{k}_{\text {fond }}=60 \mathrm{kN} / \mathrm{mm}$ for the whole length of the steel pipe; Curve $\mathrm{C}: \mathrm{k}_{\text {cent }}=5 \mathrm{kN} / \mathrm{mm}, \mathrm{k}_{\text {fond }}=60$ $\mathrm{kN} / \mathrm{mm}$ for the whole length of the steel pipe; Curve D: $\mathrm{k}_{\text {cent }}=8 \mathrm{kN} / \mathrm{mm}, \mathrm{k}_{\text {fond }}=10 \mathrm{kN} / \mathrm{mm}$ from the tunnel face to $3 \mathrm{~m}$ ahead, $\mathrm{k}_{\text {fond }}=60 \mathrm{kN} / \mathrm{mm}$ for the remaining part of the pipe ahead of the face

\section{CONCLUSIONS}

The calculations presented in this paper show how a simplified analytical model can be appropriately employed for the structural design of steel pipe umbrellas. The comparison between a three-dimensional FDM numerical model and a structural simplified scheme did indeed demonstrate satisfactory agreement, providing the load applied to the pipe is correctly chosen.

With reference to this comparison, a small rate of the Terzaghi load ranging from 0.25 to 0.15 should be applied to the multi-supported beam to guarantee a good fit to the numerical results. Furthermore the calculation emphasizes the importance of tunnel face stability and identifies the maximum bending moment acting on the pipe ahead of the tunnel face; if a large extrusion occurs at the tunnel face, the bending moments ahead of the face rise up and the risk of a pre-support failure is high.

\section{ACKNOWLEDGEMENTS}

The authors have given equal contribution to the development of the research, the analysis of the results, and the writing of the paper. 


\section{REFERENCES}

1. C.O. Aksov, T. Onargan, "The role of umbrella arch and face bolt as deformation preventing support system in preventing building damages", Tunnelling and Underground Space Technology, 25 (5), pp. 553-559, 2010

2. G. Barisone, S. Pelizza, B. Pigorini, "Umbrella arch method for tunnelling in difficult conditions - Analysis of Italian cases”. Proc. of IV International Association of Eng. Geol. New Delhi. Volume IV, Theme 2. pp.15-27, 1982

3. Barisone G., Pelizza S., Pigorini B. "Italian Experiences with Tunnel Portals in Difficult Ground". Proc. of Eurotunnel '83, Basel, Switzerland. pp.157-163, 1983

4. F. Barpi, M. Barbero, D. Peila "Numerical modelling of ground-tunnel support interaction using bedded-beamspring model with fuzzy parameters". Gospodarka Surowcami Mineralnymi, vol. 27 n. 4, pp. 71-87, 2011

5. Z. T. Bieniawski. "Engineering rock mass classifications: a complete manual for engineers and geologists in mining, civil and petroleum engineering", A. Wiley and Sons, New York, 1989

6. J.E. Bowles, "Foundation analysis and design", Mc Graw Hill,Milano, 1988

7. G. Carrieri, A. De Donati, P.G. Grasso, A. Mahtab, S. Pelizza, "Ground Improvement for Rapid Advance of Lonato Road Tunnel near Verona”, Italy. 8th Annual Conference of Tunnelling Association of Canada, Vancouver, Canada. pp.243-254, 1983

8. G. Carrieri, R. Fiorotto, P.G. Grasso, S. Pelizza. "Twenty years of experience in the use of the umbrella-arch method of support for tunnelling". International Workshop on micropiles, Venice, 2002

9. G. Galli, A. Grimaldi, A. Leonardi, "Three-dimensional modelling of tunnel excavation and lining", Computers and Geotechnics, 31(3), pp. 171-183, 2004

10. E. Hoek, "Big tunnels in bad rock". 2000 Terzaghi lecture, ASCE Journal of Geotechnical and Geoenvironmental Engineering, 127(9), pp. 726-740, 2001

11. E Hoek, C. Carranza-Torres, M. Diederichs, B. Corkum; "Integration of geotechnical and structural design in tunnelling", The 2008 Kersten Lecture, Opening Keynote Address, 56th Annual Geotechnical Engineering Conference, Minneapolis, 2008

12. R. Lancellotta, J. Calavera, "Fondazioni”, Mc Graw Hill, Milano, 1999

13. P. Lunardi, "Design and construction of tunnels - Analysis of Controlled Deformation in Rock and Soils (ADECO-RS), Springer, 2008

14. C. Marchino, L. Borio, D. Peila, "Analisi mediante modellazione numerica e modelli analitici di un presostegno con infilaggi in gallerie superficiali”, Geoingegneria Ambientale e Mineraria, XLVII (3), pp. 67-72, 2010

15. D. Merlini, D. Stocker, "Galleria di base del Ceneri, aspetti progettuali e costruttivi del contro-avanzamento al portale sud"; Geoingegneria Ambientale e Mineraria, 134(3), 2001

16. P.P. Oreste, D. Peila, A. Poma, "Numerical study of Low depth Tunnel Behaviour". Proc. of International World Tunnel Congress '99, Oslo. pp.155-162, 1999

17. P.P. Oreste, D. Peila, A new theory for steel pipe umbrella design in tunnelling. Proc. of International Tunnel Congress "Tunnel and Metropoles", San Paolo. pp.1033-1040, 1998

18. P.P. Oreste, D. Peila. "I consolidamenti come mezzo per permettere lo scavo meccanizzato di gallerie". MIR 2000, Ed. Barla, Patron Editore, Torino, 2000

19. D. Peila, D. Martinelli, A, Luciani, „Uso delle gallerie per la stabilizzazione di versanti in frana”, Geoingegneria Ambientale e Mineraria, 148 (2), pp. 61-66, 2016

20. D. Peila, "A theoretical study of reinforcement influence on the stability of tunnel face". Geotechnical and Geological Engineering. Volume 12, Chapman \& Hall, London. pp.145-168, 1994

21. D. Peila, S. Pelizza, "Ground reinforcing and steel pipe umbrella system in tunnelling", In: Rational Tunnelling, Advances in Geotechnical Engineering and Tunnelling, 8, Kolymbas Ed., Logos Verlag, Berlin pp. 93-132, 2003

22. S. Pelizza, D. Peila, "Soil and rock reinforcements in tunnelling", Tunnelling and Underground Space Technology, vol. 8(3), pp. 357-372, Pergamon Press, Oxford (UK), 1993

23. J. Shin, Y. Choi, O. Oh-Yeob Kwo, S. Lee, "Model testing for pipe-reinforced tunnel heading in a granular soil”, Tunnelling and Underground Space Technology 23, pp. 241-250, 2008

24. W. Schubert, "Experience of tunnel construction in weak ground", Geomechanics and Tunnelling, 4(3), pp. 211-220, 2011

25. A. Sorlini, A. Eusebio, C. Sacco, "Una strada di montagna al mare. La nuova viabilità di accesso a Monte Scarpino", Genova, Geoingegneria Ambientale e Mineraria, 135(1), 2012

26. G.M. Volkmann, W. Schubert, "Geotechnical model for pipe roof supports in tunnelling”, Ing. Conference Underground Space - the 4th Dimension of Metropolises , Barták, Hrdina, Romancov \& Zlámal (eds), Taylor \& Francis Group, London, 2007 
27. G. Volkmann, E. Button, W. Schubert, "A Contribution to the Design of Tunnels Supported by a Pipe Roof"; The $41^{\text {st }}$ U.S. Symposium on Rock Mechanics (USRMS), June 17-21 2006; Golden, CO, American Rock Mechanics Association, 2006

\section{LIST OF FIGURES AND TABLES:}

Fig. 1. Numerical model geometry, boundary conditions, dimensions and positions of steel pipes. In the research, the excavation of only one tunnel is considered and therefore modelled.

Rys. 1. Numeryczna geometria modelu, warunki brzegowe, wymiary i umiejscowienie rur stalowych. Badanie zostało poświęcone wykopaniu tylko jednego tunelu, co oznacza jego modelowanie.

Fig. 2. Geometry of the tunnel at the tunnel face, position of the modelled face reinforcement and detail of the position of the final lining with reference to the tunnel face.

Rys. 2. Geometria tunelu w części czołowej tunelu, umiejscowienie modelowanego wzmocnienia czołowego, oraz szczegółowe informacje na temat położenia ostatniej okładziny, w odniesieniu do części czołowej tunelu.

Fig. 3. Modelled construction sequence and advancing steps

Rys. 3. Modelowana sekwencja konstrukcji i kolejne kroki.

Fig. 4. Analytical scheme used for the multi-supported beam approach.

Rys. 4. Schemat analityczny stosowany w przypadku zastosowania podejścia wielu belek montażowych.

Fig. 5. Bending moments acting along the pipe, argillite flysch.

Rys. 5. Momenty zginające działające wzdłuż rury, fliszu argilitu.

Fig. 6. Bending moments acting along the pipe, arenaceous flysch.

Rys. 6. Momenty zginające działające wzdłuż rury, fliszu piaszczystego.

Fig. 7. Numerically computed vertical displacements compared with analytical results for the pipe in the middle of the crown in the sandstone rock mass.

Rys. 7. Przesunięcia pionowe obliczone liczbowo, w porównaniu z wynikami analitycznymi dla rury w środku korony ośrodka skalnego piaskowca.

Fig. 8. Numerically computed vertical displacements compared with analytical results for the pipe in the middle of the crown in the sandstone rock mass reducing the stiffness of the spring for the simulation of the steel arches and their foundations $\left(\mathrm{k}_{\text {fond }}\right.$ and $\left.\mathrm{k}_{\mathrm{cent}}\right)$.

Rys. 8. Przesunięcia pionowe obliczone liczbowo, w porównaniu z wynikami analitycznymi dla rury w środku korony ośrodka skalnego piaskowca, zmniejszające sztywność sprężyny do symulacji stalowych łuków i ich fundamentów ( $\mathrm{k}_{\text {fond }} \mathrm{i} \mathrm{k}_{\text {cent }}$ ).

Table 1. Geo-mechanical parameters of rock masses

Tabela 1. Parametry geomechaniczne ośrodków skalnych 
Table 2. Properties of the cable elements used to model the fibre-glass reinforcements

Tabela 2. Właściwości elementów przewodów stosowanych do modelowania wzmocnień z włókien szklanych

Table 3. Properties of the beam elements used to model the steel pipes

Tabela 3. Właściwości elementów belkowych stosowanych do modelowania rur stalowych

Received 29.07.2017

Revised 24.12.2017 


\section{PORÓWNANIE WYNIKÓW ANALITYCZNYCH I NUMERYCZNYCH MODELI WSTĘPNEGO WZMOCNIENIA W PŁYTKICH TUNELACH}

Slowa kluczowe: Budowa tunelu, wstępne wzmocnienie, rury stalowe, modelowanie numeryczne, modele analityczne

\section{STRESZCZENIE:}

System parasolowy rury stalowej jest techniką wzmocnienia gruntowego, szeroko stosowaną w drążeniu tuneli w ubogich glebach, często połączoną ze wzmocnieniem czołowym z wykorzystaniem rur z włókien szklanych. Rury stalowe są instalowane w ziemi na koronie granicy tunelu, w części czołowej tunelu, w celu poprawy zdolności samonośnych ośrodka skalnego, tym samym umożliwiając bezpieczny montaż podpór (stalowych łuków i torketu), jak również w płytkich tunelach, w celu zapewnienia stabilności podłoża i zmniejszenia ilości osadów. Technologia ta jest często łączona $\mathrm{z}$ instalacją rur $\mathrm{z}$ włókien szklanych wykorzystywanych do stabilizacji części czołowej tunelu i zapewnienia bezpiecznego osadzania rur w glebie.

Projekt jest często realizowany za pomocą uproszczonych metod analitycznych, w oparciu o definicję obciążeń zewnętrznych działających na rurę, która jest modelowana jako belka na podporach. Trójwymiarowe modele numeryczne są również często stosowane, ale ma na nie wpływ złożoność procedury obliczeniowej oraz trudności i niepewności związane $\mathrm{z}$ inicjalizacją $\mathrm{i}$ interpretacją wyników modelu numerycznego. Ponadto, opracowanie trójwymiarowego modelu stanowi nadal skomplikowaną i czasochłonną procedurę. Podejście analityczne, które jest zwykle stosowane, wymaga schematyzowania każdej rury jako belki poddanej rozłożonemu naciskowi. Połączenia rury ze stalowymi żebrami zainstalowanymi w wykopanej części tunelu są symulowane jako podpory punktowe. Belka jest osadzana w części czołowej tunelu, w glebie lub ośrodku skalnym, dlatego też rura łącząca się z podłożem jest modelowana za pomocą sprężyn, które można zaprojektować zgodnie ze schematem Winklera, jak ma to zwykle miejsce w fundamentowaniu.

Obciążenie gruntu, działające na belkę, jest zwykle traktowane jako procent całkowitego obciążenia Terzaghi podczas drążenia tuneli na średnich i dużych głębokościach lub odpowiednio do całego obciążenia gruntu, w przypadku, gdy zasięg tunelu jest mniejszy niż średnica tunelu. Największa niepewność w zakresie tej dobrze skonsolidowanej metodologii polega na prawidłowym zdefiniowaniu obciążenia wywieranego na belkę, wartość, na którą duży wpływ ma również położenie części czołowej tunelu, z powodu tworzenia się efektu łuku w tej części czołowej.

Przedstawione obliczenia pokazują w jaki sposób uproszczony model analityczny może być odpowiednio wykorzystany w projekcie konstrukcyjnym parasoli rur stalowych. Porównanie trójwymiarowego modelu numerycznego FDM z uproszczonym schematem strukturalnym wykazało w istocie dobrą zgodność, jeśli obciążenie zastosowane na rurze jest właściwie dobrane.

W przypadku tego porównania należy zastosować niewielki wskaźnik obciążenia Terzaghi mieszczący się w zakresie od 0,25 do $0,15 \mathrm{w}$ odniesieniu do belek z wieloma podporami, aby zagwarantować dobre dopasowanie do wyników numerycznych. Ponadto, obliczenia podkreślają znaczenie stabilności części czołowej tunelu i określają maksymalny moment zginający działający na rurę znajdującą się w części czołowej tunelu: w przypadku wystąpienia dużego wytłoczenia w części czołowej tunelu, momenty zginające w części czołowej rosną, a ryzyko niepowodzenia w odniesieniu do wstępnej podpory wzrasta. 
